\title{
Evidence based approach to unani contraceptives: a review
}

\author{
Saba Mohd Athar Khan*, Ismath Shameem
}

Department of Ilmul Qabalat Wa Amraze Niswan, National Institute of Unani Medicine, Bangalore, India

Received: 12 November 2015

Accepted: 12 December 2015

*Correspondence:

Dr. Saba Mohd Athar Khan,

E-mail: fairyss260888@gmail.com

Copyright: (C) the author(s), publisher and licensee Medip Academy. This is an open-access article distributed under the terms of the Creative Commons Attribution Non-Commercial License, which permits unrestricted non-commercial use, distribution, and reproduction in any medium, provided the original work is properly cited.

\begin{abstract}
Contraception is a process or technique for preventing pregnancy by means of medication, device or method that blocks or alters one or more of the processes of reproduction in such a way that sexual union can occur without impregnation. Promotion of family planning is central to the World Health Organization work on improving maternal health \& is core to achieve the Millennium Development Goal. It is estimated that $90 \%$ of abortion related and $20 \%$ of pregnancy related morbidity and mortality, could be prevented by the use of effective contraception. Population explosion is the leading cause of poverty and pollution in developing countries which has detrimental effect on the life supporting system. Hence it is necessary to control the population by the use of contraceptives. Available contraceptives in conventional medicines have many adverse effects. Therefore, there is a need for research of newer, less expensive, less toxic, self-administered, completely reversible contraceptives. Much of these properties are observed in contraceptives as mentioned in classical Unani text. Unani physician has mentioned the various medicines \& techniques of contraceptives. Scientific research has confirmed the efficacy of most of the herbal drugs like Ruta graveolans (Suddab), Juniperus communis (Abhal), Piper longum (Filfil daraz), Mentha arvensis (Pudina), Azadirachta indica (Neem), Punica granatum (Anar), Alium cepa (Piyaz) and Daucus carota (wild carrot) etc. Therefore, the aim of this article is to review the ancient concept of contraception in Unani System of Medicine in the light of available scientific research.
\end{abstract}

Keywords: Unani medicine, Contraceptive, Herbal drugs

\section{INTRODUCTION}

Asia is home to 60 percent of global population. China and India account for more than half of Asia's total population. ${ }^{1}$ India is the second most populous country in the world, with over 1.27 billion people (2015). Already containing $17.5 \%$ of the world's population, India is projected to be the world's most populous country by 2030, surpassing China. ${ }^{2}$ This increment imposes an extra burden on the community and it is also one of the leading causes of poverty and pollution in developing countries. Fertility Control is an issue of global and national public health concern. ${ }^{3}$

Contraception is a process or technique for preventing pregnancy by means of medication, device or methods that blocks or alters one or more of the processes of reproduction in such a way that sexual union can occur without impregnation. An estimated 222 million women in developing countries would like to delay or stop childbearing but are not using any method of contraception. It is estimated that satisfying the unmet need for family planning alone could cut the number of maternal deaths by almost a third. The UN SecretaryGeneral's Global Strategy for Women's and Children's Health aims to prevent 33 million unwanted pregnancies between 2011 and 2015 and to save the lives of women who are at risk of dying of complications during pregnancy and childbirth, including unsafe abortion to reduce maternal mortality. Contraceptive goals are on higher priorities to achieve Millennium Development Goals, especially for those concerned with child 
mortality, maternal health, HIV/AIDS, and gender equality. ${ }^{4}$

Modern medicine has provided several preventive and corrective methods of contraceptives none of which is safe, effective and have side effects which include obesity, VTE, cholelithiasis, carcinoma of breast and cervix, asthma, intermenstrual bleeding, headache, mood swings, breast tenderness and loss of libido. ${ }^{5}$ The World Health Organization suggested that effective, locally available plants to be used as substitutes for these drugs and population control programs are created which includes studies of traditional medical practices. ${ }^{3}$

Thorough literature survey of Unani reveals that there are many plants origin drugs having scientifically proved contraceptive effect with little or no side effect.

\section{METHODS}

For Unani concept of contraceptive, available authentic text of Unani Medicine was searched. Literature was also searched on PubMed/Google scholar with the keywords; Herbs for contraception, phytoestrogens, anti-ovulatory, anti-implantation, spermicidal, anti-spermatogenic.

\section{Historical background}

Concept of family planning emerges in early 8th decade of 20th century (1971) when the world's gross population surpasses 3 Billion with accelerating growth rate, but the use of contraception dated back to almost 4000 years. The Kahun Papyrus, an Egyptian papyrus (1850 BC) is probably the first text book on gynecology and discovered to possess number of prescription for contraception viz, local use of paste containing crocodile dung, ${ }^{7}$ it is believed that the low $\mathrm{pH}$ of the dung may have had spermicidal effect. ${ }^{8}$ In earliest time people used various plant and animal products to block the cervix and absorbs semen, these were vegetable seed, plugs of grass, crushed roots, empty halves of pomegranates, squeezed half of lemon and rock salts etc. Also in Ebers papyrus $(1550 \mathrm{BC})$ it is mentioned that a mixture of acacia tips, bitter apple and dates bound together with honey and placed in the vulva as spermicidal, ${ }^{9}$ It probably had some effectiveness, in part as a physical barrier due to the thick, sticky consistency, and also because of the lactic acid (a known spermicide) formed from the acacia. ${ }^{8}$ Hippocrates (460-377 BC) in his treatise "Nature of Women" described 'coitus interruptus' and 'using finger to wipe out vagina' for contraception. He had also mentioned the use of Wild Carrot (Daucus carrota) as an oral contraceptive. ${ }^{10}$ Pomegranate was the first hormonal contraceptives widely used by Greek women. ${ }^{11}$ The famous Greek philosopher Aristotle (384-322 B.C.) proposed the idea of family planning and prescribed several remedies like local application of oil of Cedar, ointment of Lead etc. which formed a barrier or had spermicidal effect. ${ }^{12}$ The next documented reference of contraceptive method mentioned in Bible, The Book of
Genesis was coitus interruptus. ${ }^{9}$ Doiscorides (40-90 AD) recommended suppositories of peppermint or sicklewort mixed with honey and mentioned several other drugs for contraception. His book, De Materia Medica, was a standard resource for contraceptive information until $16^{\text {th }}$ century. The concept of abstinence during fertile period, to avoid conception, was given by Soranus of Ephesus, a famous Roman physician during second century (fertility awareness based methods). Galen (130-200 AD) made his contribution to the subject by mentioning several drugs bearing upon procreation, in his book Kitab ul Advia al Mufradah. ${ }^{12}$ In middle ages during glorious era of Arabic medicine, contraception was thought to be worthy of discussion thus, an extensive information about the indication, methods, prescriptions, contraindications and even their mechanism of action put in by legendary.

Personalities of the era like Mohammed Ibn Zakariya Razi, Ali Ibn Abbas Majoosi, the great philosopher Abu Ali Sina, and Ibn Baitar. In $12^{\text {th }}$ century, an excellent medical compendium Zakheera khwarzam Shahi was written by sharfuddin Ismail Jurjani (110 AD) where he first described the method of wrapping the penis with a soft cloth before coitus to avoid conception which led to think of modern day condom. ${ }^{13}$ several natural and barrier methods invented since then.

Intrauterine contraceptive devices: The discovery of modern IUD can be traced back to the Arabs who inserted pebbles into the uteri of their camels to protect them against pregnancy during long journeys. In $11^{\text {th }}$ century Islamic scientist Avicenna used intrauterine Pessaries for contraception in women. ${ }^{11}$

\section{Indications}

Contraceptives were prescribed by Eminent Unani physician only in the following conditions: If pregnancy will result in higher risk to maternal complication and death, major systemic illnesses, infantile uterus, congenital urogenital malformation and mentally ill women. $^{13-15}$

\section{Techniques of contraception}

Techniques for preventing the entrance of semen in the uterus. Coitus interruptus, Insertion of some tablets and suppositories of drugs into vagina so that opening of uterus is closed thereby prevent entrance of semen in the uterus. Techniques to be adopted if the semen has entered the uterus: The couple should retrieved quickly after the sexual union, and the women should sneeze, shout loudly, jump repeatedly on back side so as to remove ejaculate from the vagina before fertilization. The more effective method was to induce menstruation before fertilization or implantation can take place by many Unani medicines. $^{13-18}$ 


\section{Evidence based research on unani contraceptives}

The ancient literature of Unani medicine is very rich in contraceptive drugs for permanent as well as temporary sterilization, in the form of oral or local applications. Drugs are used orally either in the form of powder or extract, while the locally applied drugs have been prescribed in various dosage forms, viz. suppository, pessary, liniment, douche, sitz bath, ointment, fumigation and paste to be applied on the male or female genital organs and scientific research has confirmed the efficacy of most of the Unani drugs. Plants that have contraceptive properties may act as antiovulatory, antiimplantation, abortifacient, anti spermatogenic and spermicidal.

\section{PHARMACOLOGICAL STUDIES ON UNANI CONTRACEPTIVES}

\section{Neem oil (Azadiracta indica) [Figure 1]}

Azam Khan a great Unani physician in his book Akseer Azam mentioned that if women consume $4.5 \mathrm{gm}$ of Neem oil orally it leads to sterility. Neem oil, extracted from the seeds of the neem tree, has been found to possess strong spermicidal activity and anti-implantation activity due to presence of chemical constituent namely Nimbidin, Nimbin, ${ }^{19}$ Azadirachtin and NIM-76. Intravaginally the oil prevented pregnancy in rats $(20 \mu \mathrm{l})$, rhesus monkey and women $(10 \mathrm{ml})$. Oral dose of $25 \mu \mathrm{l}$ neem oil shows anti-implantation effect in rats. ${ }^{8}$

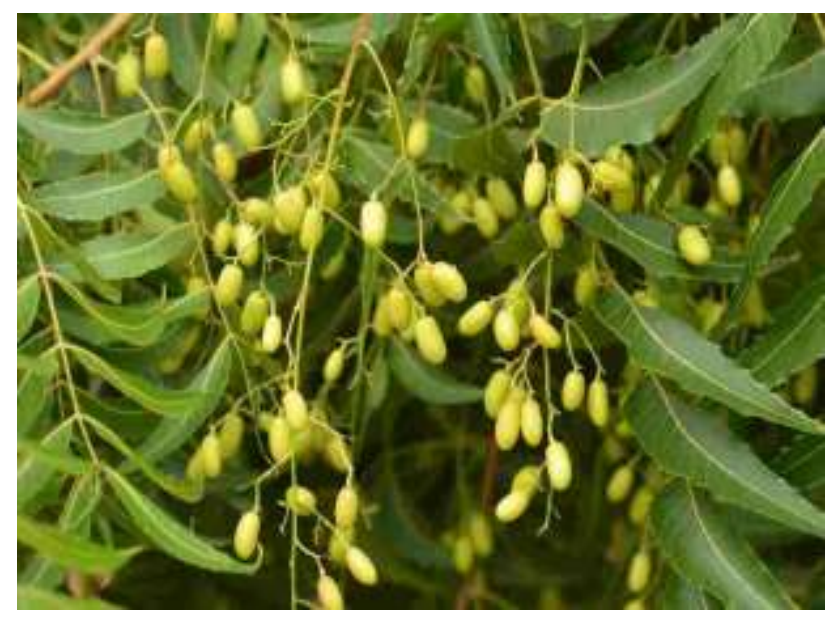

Figure 1: Azadirachta indica.

\section{Filfil daraz, / Black pepper (Piper longum) [Figure 2]}

It act as a postcoital emergency contraceptive when it is used as a pessary mentioned in Al Hawi, Zakhire Khwarzam Shahi \& Ghana Mana. ${ }^{17,18}$ Recent scientific studies showed that $20 \mathrm{mg} / \mathrm{ml}$ hexane extract of Piper longum possesses potential contraceptive spermicidal activity in vitro as it contains compound 'Piperine'. ${ }^{20}$

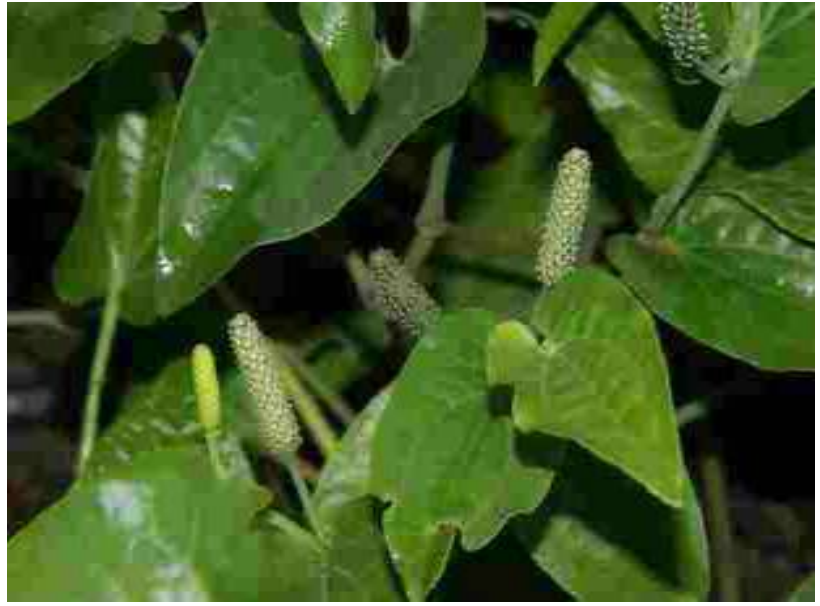

Figure 2: Piper longum.

\section{Pudina/ Pepper Mint (Mentha arvensis) [Figure 3]}

It has been mentioned in various Unani books that use of pessary made up of Pepper Mint extract before coitus act as a contraceptive. ${ }^{13,15,17}$ Recent study shows that uterotonic fraction of Mentha arvensis has antiimplantation activity by enhancing the estrogenic effect of estradiol as it contains menthol, menthone, camphene. $^{21}$

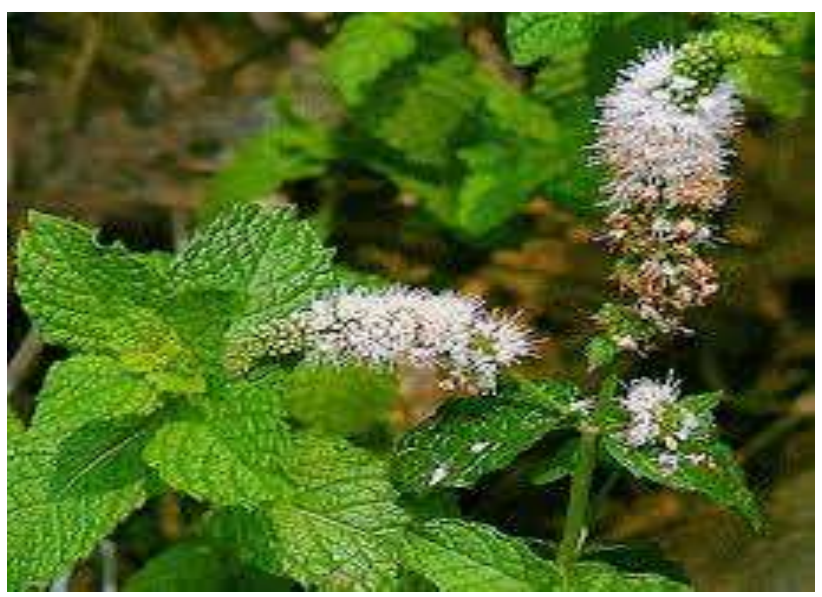

Figure 3: Mentha arvensis.

\section{Wild carrot/Queen Anne's lace (Daucus carota) [Figure 4]}

The earliest written reference dates back to the late 5 th or 4th century B.C. appearing in a work written by Hippocrates. They should be chewed within 8 hours of being exposed to sperm. ${ }^{22}$ The seed inhibits the implantation of fertilized egg by disrupting the endometrial lining. It possesses weak oestrogenic property at dose of $80 \& 120 \mathrm{mg} / \mathrm{mouse}$ orally from day 4 to day 6 post coitum due to presence of flavones, apigenine and quercetine. ${ }^{21,23}$ 


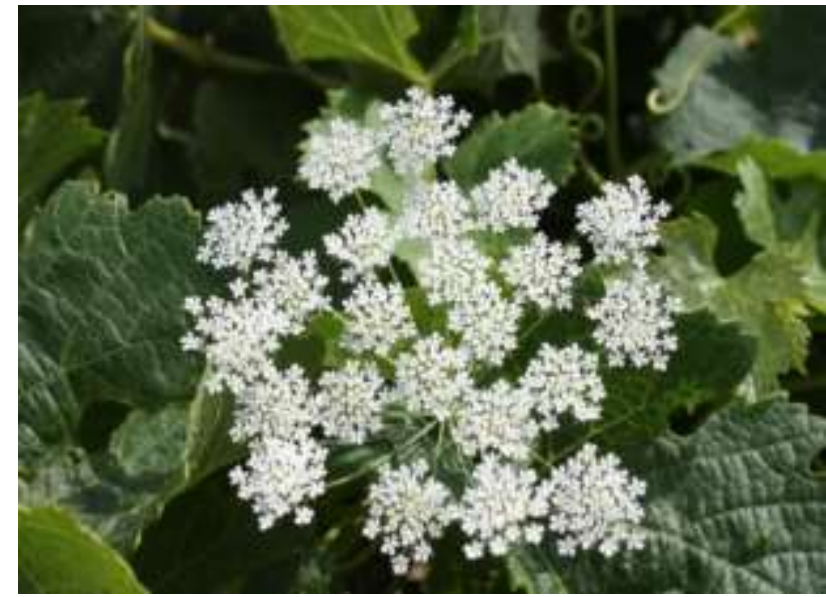

Figure 4: Daucus carota.

\section{Anar/Pomagranate (Punica granatum) [Figure 5]}

Ali Ibn Abbas Majoosi in his treatise Kamil us Sana mentioned the use of $P$. granatum with Aluminium hydroxide by female in the form of pessary before coitus prevent conception. $50 \%$ of ethanol extract of it showed anti-impalntation activity in rats. ${ }^{24}$ The seeds of the fruit contain oestrone identical to hormone estrogen are the best source of plant oestrogen to date and decreases follicular growth. ${ }^{25}$ Rind of pomegranate possesses tannins a type of polyphenols which exhibits spermicidal activity. $^{26}$

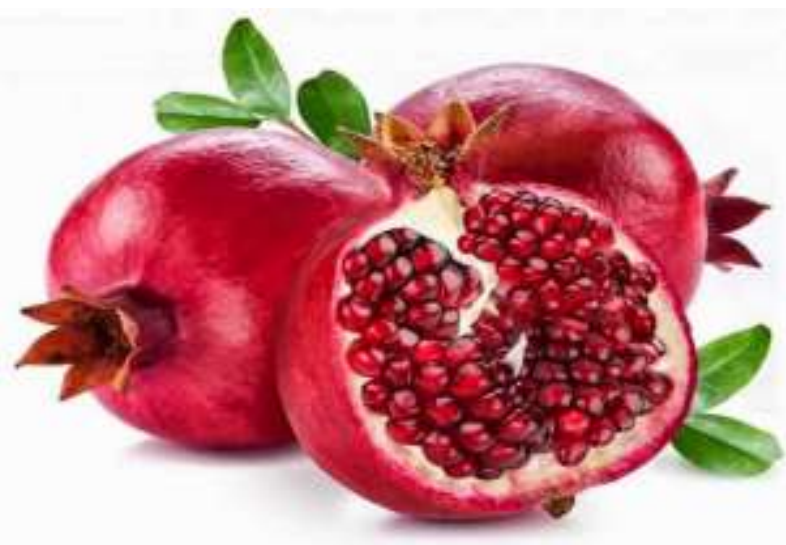

Figure 5: Punica granatum.

\section{Onion (Alium cepa) [Figure 6]}

Extract of Allium cepa is to be used as ointment on the glans penis in male and in the form of pessary in female. ${ }^{17,18}$ Ethanolic extract of Allium cepa showed significant anti-implantation activity at the dose of 300 $\mathrm{mg} / \mathrm{kg}$ in mice. ${ }^{27}$

\section{Suddab/Garden rue (Ruta graveolens) [Figure 7]}

Majoosi recommends the fresh leaves of rue as pessary to prevent conception. Aqueous extract of Ruta graveolans has immobilizing effect on human sperm at a concentration of $100 \mathrm{mg} / \mathrm{ml}$ of lyophilized form in $1: 1$ ratio can immediately immobile sperm cell in semen sample as it posseses acridine, alkaloids, acoumarine, essential flavonoids and furoquinolines. ${ }^{21,28}$

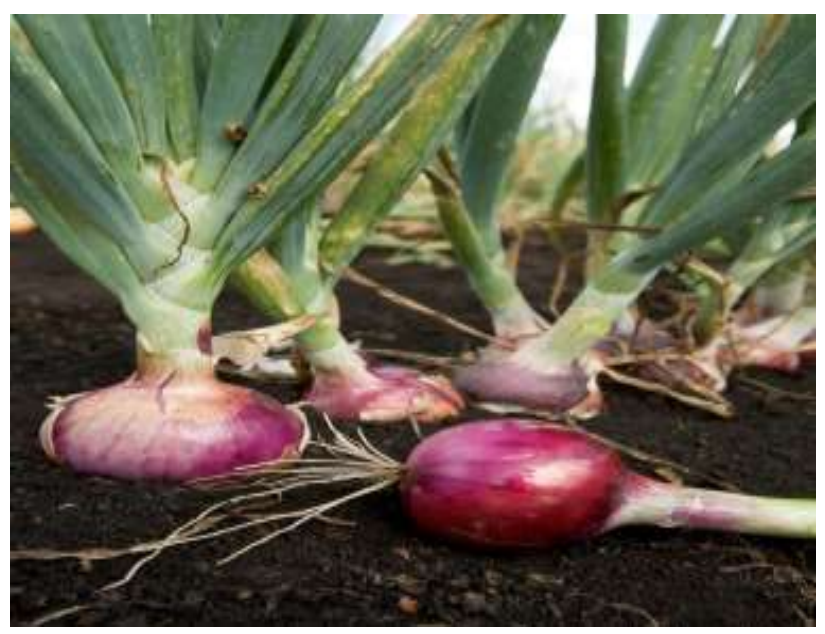

Figure 6: Alium cepa.

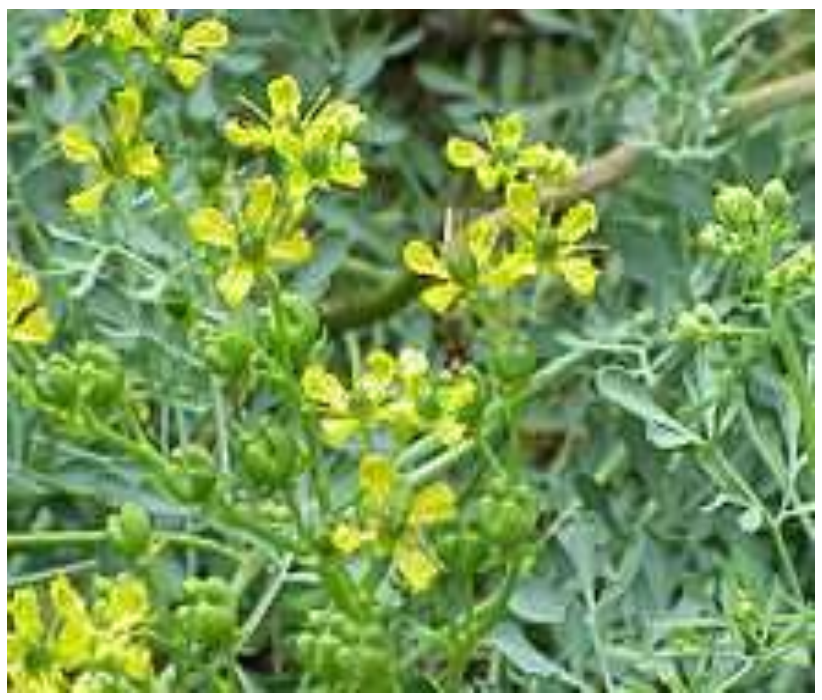

Figure 7: Ruta graveolans.

\section{Abhal/Common Juniper (Juniperus communis) [Figure 8]}

Compound made up of Abhal (Juniperus communis), Heeng (Ferula asafetida), Ushq (Dorema ammonicum) each $2 \mathrm{gm}$ in the form of tablet result in miscarriage ${ }^{29}$ or local application of paste made by $5 \mathrm{gm}$ powder of Abhal, Suddab and Natroon (Pinus Sylvester) before coitus on penis act as contraceptive. ${ }^{15} 50 \%$ ethanolic extract of juniper fruit has anti-implantation activity in Swiss albino female rats at $300 \mathrm{mg}$ and $500 \mathrm{mg} / \mathrm{kg}$ body weight was administered orally from $\mathrm{D}_{1}-\mathrm{D}_{7}$ of pregnancy $^{30}$ due to its anti-progestational activity ${ }^{31}$ because of the presence of monoterpenes, tannins (gallocatechins) and flavonoids (quercitin). ${ }^{21}$ 


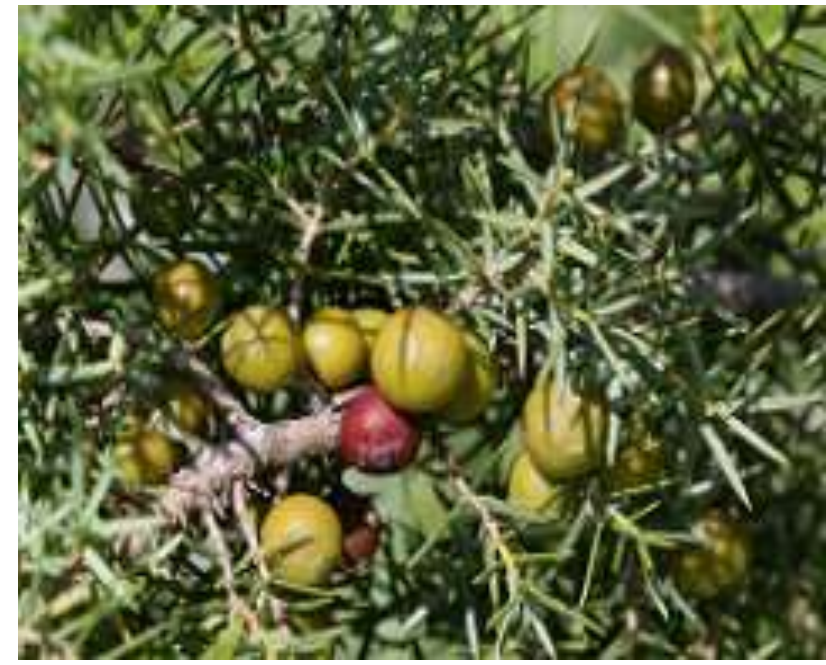

Figure 8: Juniperus communis.

\section{Safeda/ White Lead [Figure 9]}

Local use of ointment of white lead on penis before coitus act as contraceptive as mentioned in Al Qanoon \& Ghana Mana. ${ }^{15,16}$ In vitro effect of white lead on human sperm disturb the sperm metabolism by inhibition of Creatine kinase activity and thereby reducing sperm motility. ${ }^{18}$

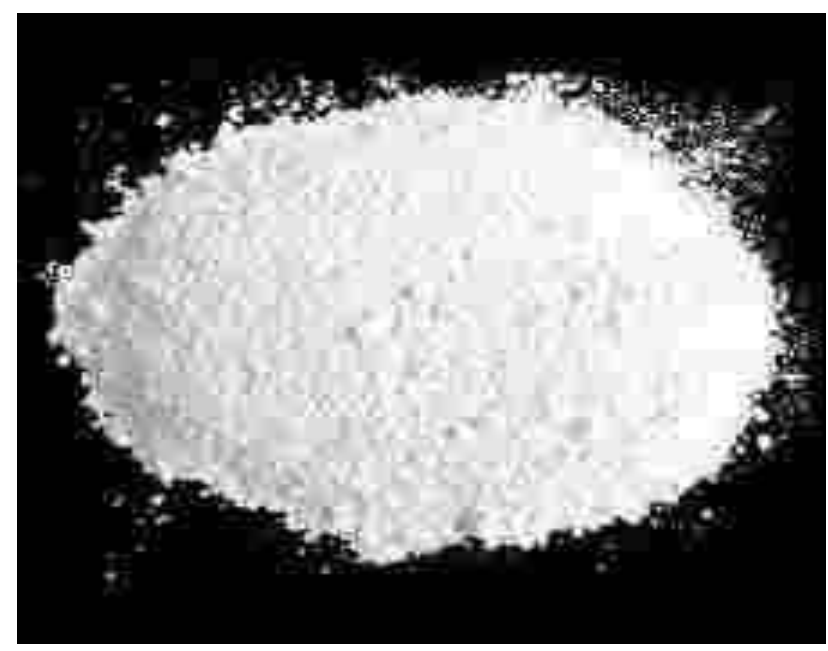

Figure 9: White Lead.

\section{Halelaa/ Chebulic Myrobalan (Terminalia chebula): [Figure 10]}

HKM Mohd. Aazam khan in his treatise Aksee-re-Azam mentioned that the use of halelaa in the form of pessary prevents conception. Aqueous-ethanolic (1:1) extract of fruit of $T$. Chebula exerts a significant antispermatogenic effect in male rat by inhibition of hyaluronidase activity of human and rat spermatozoa in vitro as it is rich in flavonoid. ${ }^{33}$

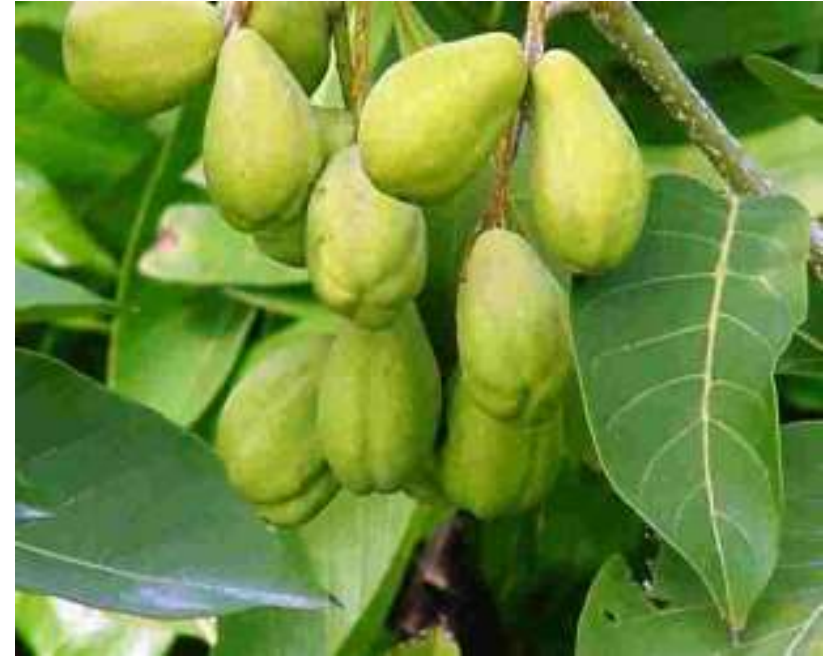

Figure 10: Terminalia chebula.

Hanzal/ Colocynth Bitter Apple (Citrullus colocynthis): [Figure 11]

Shaham-e-Hanzal (Citrullus Colocynthis), Saqmoonia (Convulvullus scamony), Hazarjashan (Bryonia alba), Khabs-al-Hadeed (Iron rust), and Tukhm Karnab (Brassica oleracea) in equal quantity should be powdered, Mixed with Qatran (Pinus sylvestris) and be used as pessary after menstruation as a contraceptive. ${ }^{15-18}$ Oral administration of $70 \%$ methanolic extract of $C$. colocynthis at the dose of 75 and $150 \mathrm{mg} / \mathrm{kg}$ body weight/day to male albino rats for 60 days caused a significant decrease in testicular weight and sperm concentration. The antifertility effects of $C$. colocynthis is mediated by disturbances in structure and testicular function including leydig and Sertoli cells resulting in an alteration in physio-morphological events of spermatogenesis. $^{34}$

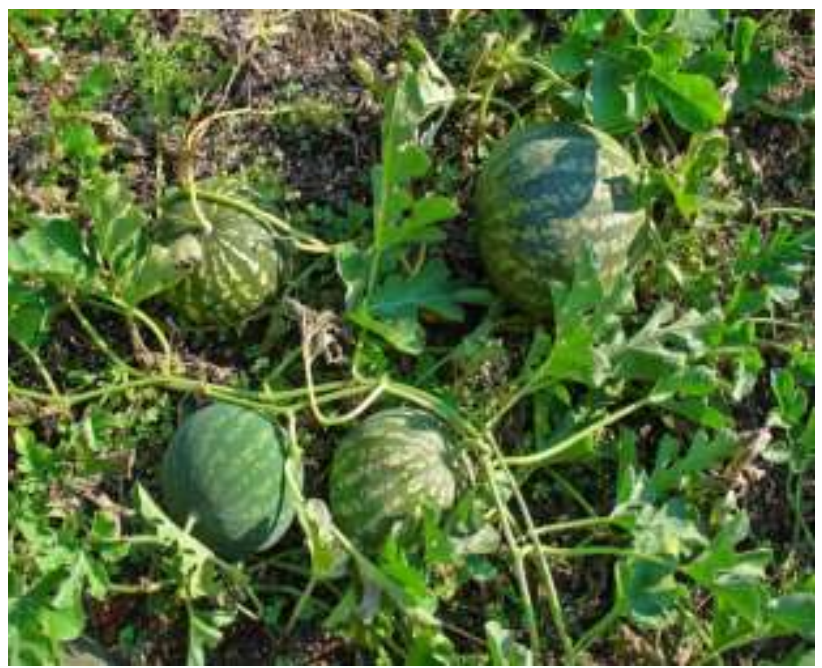

Figure 11: Citrullus colocynthis. 
Table 1: List of Unani Contraceptives with pharmacological studies.

\begin{tabular}{|c|c|c|c|c|c|}
\hline Sr.no & Name of drugs & Activity & Effect & Active ingredients & Author/Year \\
\hline 1. & $\begin{array}{l}\text { Asgandh } \\
\text { Withania somnifera } \\
\text { (stem) }\end{array}$ & Spermicidal & $\begin{array}{l}\text { Decrease sperm } \\
\text { motility, sperm density }\end{array}$ & Alkaloid & $\begin{array}{l}\text { Shekhawat et } \\
\text { al, } \\
2013\end{array}$ \\
\hline 2. & $\begin{array}{l}\text { Papita } \\
\text { Carica papaya } \\
\text { (seeds) }\end{array}$ & Antispermatogenic & $\begin{array}{l}\text { Reduced } \\
\text { spermatogenesis, } \\
\text { inhibition of steroidal } \\
\text { hormone }\end{array}$ & $\begin{array}{l}\text { Caricain, } \\
\text { carpasemine,oleanoilc } \\
\text { glycoside }\end{array}$ & $\begin{array}{l}\text { Changamma } \\
\text { et al, } 2013\end{array}$ \\
\hline 3. & $\begin{array}{l}\text { Turanj } \\
\text { Citrus medica } \\
\text { (seeds) }\end{array}$ & $\begin{array}{l}\text { Anti-implantation } \\
\text { Antiovulatory } \\
\text { Abortifacient }\end{array}$ & $\begin{array}{l}\text { Increased ovarian } \\
\text { weight, decrease } \\
\text { Graffian follicles, } \\
\text { irregular estrous } \\
\text { cycle }\end{array}$ & $\begin{array}{l}\text { Citroflavanoids, } \\
\text { Glucosides, } \\
\text { Terpenoids }\end{array}$ & $\begin{array}{l}\text { Tahaet al, } \\
2012\end{array}$ \\
\hline 4. & $\begin{array}{l}\text { Sharifa } \\
\text { Annona squamosal } \\
\text { (seed, leaves, bark) }\end{array}$ & Abortifacient & Induces early abortion & $\begin{array}{l}\text { Alkaloids } \\
\text { Annonaine }\end{array}$ & $\begin{array}{l}\text { Vijayalaxmi } \\
\text { et al } 2011 \text {, }\end{array}$ \\
\hline 5. & $\begin{array}{l}\text { Zard Chob } \\
\text { Curcuma longa } \\
\text { (Rhizome) }\end{array}$ & $\begin{array}{l}\text { Antiovulatory } \\
\text { Antifertility }\end{array}$ & $\begin{array}{l}\text { Decreased ovarian wt } \\
\text { Suppression of GnRH }\end{array}$ & $\begin{array}{l}\text { Curcumin, } \\
\text { Flavanoids }\end{array}$ & $\begin{array}{l}\text { Amit et al, } \\
2011\end{array}$ \\
\hline 6. & $\begin{array}{l}\text { Amaltaas } \\
\text { Cassia fistula } \\
\text { (fruits, bark) }\end{array}$ & $\begin{array}{l}\text { Anti-implantation } \\
\text { Estrogenic }\end{array}$ & $\begin{array}{l}\text { Decrease glycogen } \\
\text { content in uterus }\end{array}$ & Alkaloids & $\begin{array}{l}\text { Panda, et al } \\
2011\end{array}$ \\
\hline 7. & $\begin{array}{l}\text { Fufal } \\
\text { Areca catechu } \\
\text { (fruit/seed) }\end{array}$ & Antiovulatory & $\begin{array}{l}\text { Ovarian weight } \\
\text { decreased due to } \\
\text { imbalance in } \\
\text { gonadotropin }\end{array}$ & $\begin{array}{l}\text { Arecaidine, } \\
\text { Arecoline, } \\
\text { Pilocarpine }\end{array}$ & $\begin{array}{l}\text { Jyoti et al, } \\
2010\end{array}$ \\
\hline 8. & $\begin{array}{l}\text { Sheetraj hindi } \\
\text { Plumbago } \\
\text { zeylanica } \\
\text { (Leaves) }\end{array}$ & Antiovulatory & $\begin{array}{l}\text { Inhibition of ovulation } \\
\text { with irregular estrous } \\
\text { cycle }\end{array}$ & $\begin{array}{l}\text { Plumbagin, } \\
\text { Sitosterol, } \\
\text { glycosides,Tannins } \\
\text { Fatty alcohol }\end{array}$ & $\begin{array}{l}\text { Sheeja et al, } \\
2009\end{array}$ \\
\hline 9. & $\begin{array}{l}\text { Gule Gurhal } \\
\text { Hibiscus } \\
\text { rosasinensis } \\
\text { (root, flower) }\end{array}$ & $\begin{array}{l}\text { Anti-implantation } \\
\text { Antiovulatory }\end{array}$ & $\begin{array}{l}\text { Increased uterine } \\
\text { weight, increase in } \\
\text { secretion of estrogen } \\
\text { by atretic follicles }\end{array}$ & $\begin{array}{l}\text { Cyclopeptide } \\
\text { alkaloids }\end{array}$ & $\begin{array}{l}\text { Basu deva et } \\
\text { al, } \\
2007\end{array}$ \\
\hline 10. & $\begin{array}{l}\text { Chirchita } \\
\text { Achyranthes aspera } \\
\text { (roots) }\end{array}$ & $\begin{array}{l}\text { spermicidal } \\
\text { Anti-implantation } \\
\text { Antiovulatory }\end{array}$ & $\begin{array}{l}\text { Hormonal disturbance } \\
\text { Expulsion of ova }\end{array}$ & Achyranthine & $\begin{array}{l}\text { Sharma er al, } \\
2007\end{array}$ \\
\hline 11 & $\begin{array}{l}\text { Neem } \\
\text { Azadirachta indica } \\
\text { (Flower,seeds, } \\
\text { leaves) }\end{array}$ & $\begin{array}{l}\text { spermicidal } \\
\text { Antifertility }\end{array}$ & $\begin{array}{l}\text { Effect on number of } \\
\text { spermatozoa and } \\
\text { Level of fructose }\end{array}$ & $\begin{array}{l}\text { Azadirachtin } \\
\text { Cyclopeptide } \\
\text { Alkaloid }\end{array}$ & $\begin{array}{l}\text { Mishra et al, } \\
2005 \\
\text { Jegede et al, } \\
2008\end{array}$ \\
\hline 12. & $\begin{array}{l}\text { Gilo } \\
\text { Tinospora } \\
\text { cordifolia }(\text { stem) }\end{array}$ & $\begin{array}{l}\text { spermicidal } \\
\text { Antifertility }\end{array}$ & $\begin{array}{l}\text { Reduced weight of } \\
\text { Testis, sperm count. }\end{array}$ & $\begin{array}{l}\text { Berberine, } \\
\text { Palmatine D } \\
\text { Choline D }\end{array}$ & $\begin{array}{l}\text { Gupta et al, } \\
2003 \\
\text { Choudhray et } \\
\text { al } \\
2013\end{array}$ \\
\hline 13. & $\begin{array}{l}\text { Piyaz } \\
\text { Allium cepa } \\
\text { (Bulb) }\end{array}$ & Anti-implantation & $\begin{array}{l}\text { Inhibition of number of } \\
\text { implant sites }\end{array}$ & $\begin{array}{l}\text { Kampferol } \\
\beta \text { - sitosterol, } \\
\text { ferulic acid, myritic } \\
\text { acid }\end{array}$ & $\begin{array}{l}\text { Thakare et al, } \\
2003,2009\end{array}$ \\
\hline 14. & $\begin{array}{l}\text { Tukhm-e-Taratezak } \\
\text { Lepidium sativum } \\
\text { (seeds, roots) }\end{array}$ & Antiovulatory & Reduced level of GnRH & Lepidine & $\begin{array}{l}\text { Pande et al, } \\
2002\end{array}$ \\
\hline 15. & $\begin{array}{l}\text { Madar } \\
\text { Calotropis procera } \\
\text { (root) }\end{array}$ & Antiovulatory & $\begin{array}{l}\text { Prolonged dioestrous } \\
\text { stage with temporary } \\
\text { inhibition of ovulation }\end{array}$ & Steroidal alkaloids & $\begin{array}{l}\text { Circosta et al, } \\
2001\end{array}$ \\
\hline
\end{tabular}




\section{CONCLUSIONS}

In classical literature of Unani medicine, physicians had described in detail both oral and local (pessary, fumigation, douches, sitz bath ointment, paste) forms of contraceptives. Modern scientific research on animals has confirmed antifertility effect in most of the drugs. However, there are many limitations regarding the safety and efficacy of these preparations to be used in human beings. Hence, there is need for further clinical studies to establish the efficacy \& safety of these drugs.

\section{ACKNOWLEDGEMENTS}

Authors are thankful to authors, editors and publishers of all those books and journals from where the literature for this article has been reviewed, discussed and cited.

Funding: No funding sources

Conflict of interest: None declared

Ethical approval: Not required

\section{REFERENCES}

1. Population reference bureau. 2014 world population data. 2015Aug; USAID publication. Available from:http://www.pbs.org. Accessed on 28 October 2015.

2. Population of India. Available at http:// www.indiaonlinepages.com/population/india currentpopulation.html. Accessed on 24 August 2015 at 6:25 p.m.

3. Umadevi M, Kumar SPK, Bhowmik D, Duraivel S. Medicinal plants with potential antifertility activity. J Med Plants Studies. 2013;1(1):26-33.

4. Bernstein S. UN millennium project report. United Nation: population, reproductive health and the millennium development goal: 2005 .

5. Wolski H. Selected aspect of oral contraceptive side effects. Pub Med. 2014;85(12):944-49.

6. Rajan TS, Sarathchandiren I, Kadalmani B. Investigation of herbal oral contraceptive suspensions for its antisteroidogenic and antioxidant properties. Int J Pharm Biomed Sci. 2013;4(1):50-8.

7. Evolution and revolution the past present and future. Contraception Report. 2000;10(6):12.

8. Asif M. A review on spermicidal activities of Azadiracta indica. J Pharmacogn phytochem. 2013;1(15):61-79.

9. Sneader W. Drug Discovery A History [Internet] England: John Willey and Sons Ltd; 2005. Available at: http://gzy.hainmc.edu.cn/ jingpin/yl/jxzy/ckwx/ drug\%20discovery1.pdf. Accessed on 21 October 2015.

10. Hopkins K. Contraception in the Roman Empire. Contraceptive studies in society and history. $1965 ; 13: 124$.

11. Schorge OJ, Schaffer IJ, Halvarson ML, Hoffman LB, Bradshaw DK, Cunningham GF. Williams
Gynecology. 21st ed. China: The McGraw-Hill Companies; 2008:449-453.

12. Razzack MA, Fazal U. The concept of birth control in Unani medicine. New Delhi:CCRUM; 1993:3,5563.

13. Jurjani AH. Zakheera Khawarzam Shahi (Urdu translation by Khan HH). Vol. 02. Part 06. Lucknow: Matba Munshi Navi Kishore; 1903:623-624.

14. Majusi AA. Kamil Us Sanaa (Urdu translation by Kanturi GH). Vol. 2. Lucknow: Matba Munshi Naval Kishore; 1889:502.

15. Khan MA. Al Akseer (Urdu translation). Vol. 2. New Delhi: Ejaz publishing house; 2003:1401-1403.

16. Sina I. Al Qanoon Fit Tib (urdu translation by kanturi GH) Vol. 03. New Delhi: Idara Kitabul Shifa; 2010:1082-1083.

17. Zakaria Razi. Kitab Al Hawi (Urdu translation by (CCRUM). Volume. 9. New Deilhi: Ministry of Heaith and Family Welfare; 1999:120-150.

18. Alqamri MH. Ghana Mana. New Delhi: CCRUM; 2008:397-398.

19. Bhowmik D, Chiranjib, Yadav J, TripathiK, Kumar KP. Herbal remedies of Azadirachta indica and its Medicinal Application. J Chem Pharm Res. 2010;2(1):62-72.

20. Sarwar AH, Nirala RK, Arif M, Khilare B, Thakur SC. Spermicidal activity of the hexane extract of Piper longum: an in vitro study. Pub Med. 2015;29(12):1166-9.

21. Khare CP. Indian Medicinal plants An Illustrated Dictionary [Internet]. New Delhi: Springer; 2001. Available at: http://www.tee.org/fileadmin/ downloads/Botanische\%20Bestandsaufnahme\%20in discher\%20Heilpflanzen.pdf. Accessed on 28 October 2015.

22. Shweta G, Chetna R, Jinkal S, Nancy S, Hitesh J. Herbal plants used as contraceptive. Intern J Curr Pharm Rev Res. 2011;2(1):47-53.

23. Ibrahim SR, Mohammed JA, Haidri RA. A review on natural contraceptive agents. Am J Pharm Tech Res. 2014;4(3):124-57.

24. Prakash AO et al. Anti-implantation activity of some indigenous plants in rats. Pub med. 1985;16(6):44148.

25. Priya G, Saravanan K, Renuka C. Medicinal plant with potential antifertility activity. IJPRIF. 2012;4(1):481-94.

26. Zhou B, Qiu Z, Liu G, Liu C, Zhag J. Spermicidal and antigonococcal effects of tannins from pomegranate rind. J med plants res. 2012;6(7):13349.

27. Thakare VN, Khotavade PS, Dhote VV, Deshpande AD. Antifertility activity of ethanol extract of Allium cepa Linn in Rats. IJPTR. 2009;1(1):73-8.

28. Harat ZN, Sadeghi MR, Sadeghipour HR, Kamalinejad M, Eshraghian MR. Immobilization effect of Ruta graveoalns $L$. on human sperm: a new hope for male contraceptive. J Ethnopharmacol. 2008;115:36-41. 
29. Itrat M, Arsahd Jamal M, Zarnigar, Siddiqui MA. A review of contraceptive drugs described in Unani literature. J Biol Sci Opinion. 2013;1(3):278-81.

30. Agrawal P, Bharadwaj S, Mathur R. Antifertility effect of fruits of Juniperus communis. Thieme Plant Medica. 2008;40:98-101.

31. Pathak S, Tewari rk, Prakash AO. Hormonal properties of ethanolic extract of Juniperus Communis Linn. Ancient Sci Life. 1990;10(2):10613.

32. Ghaffari MA, Motlaqh B. In vitro effect of lead on human sperm creatine kinase. Pub Med. 2011;15(1):38-43.

33. Ghosh A, Jana K, Pakhira BP, Tripathy A, Ghosh D. Antifertility effect of aqueous ethanolic (1:1) extract of the fruit of Terminalia Chebula: rising approach towards herbal contraception. Asia Pacific J. 2015;4(3):201-07.

34. Joshi CS, Sharma A, Sharma P, Chaturvedi M. Contraceptive efficacy of Citrulus Colocynthis methanolic extract in male rats. Am J Phytomed clin Therap. 2014;2(2):229-41.

Cite this article as: Khan SMA, Shameem I.

Evidence based approach to unani contraceptives: a review. Int J Reprod Contracept Obstet Gynecol 2016;5:268-75. 